
\title{
$\angle S$ Research Suare \\ Mediational Links for the Severity of Anorexia and Bulimia a Path Analysis Study
}

\section{Geovanny Genaro Reivan Ortiz ( $\sim$ greivano@ucacue.edu.ec)}

Universidad Católica de Cuenca: Universidad Catolica de Cuenca https://orcid.org/0000-0003-0643-8022

\section{Roser Granero Perez}

Universitat Autònoma de Barcelona: Universitat Autonoma de Barcelona

\section{Patricia Ortiz Rodas}

Universidad de Cuenca

\section{Research Article}

Keywords: anorexia, bulimia, mediation, emotional regulation, perfectionism, anxiety, depression.

Posted Date: May 17th, 2021

DOI: https://doi.org/10.21203/rs.3.rs-489720/v1

License: (1) This work is licensed under a Creative Commons Attribution 4.0 International License. Read Full License 


\section{Abstract}

Background: to date there is empirical evidence on the associations between anorexia and bulimia nervosa with psychopathological constructs (anxiety, depression, perfectionism, emotional dysregulation) and sociodemographic characteristics (gender and place of origin). However, there are no studies that analyze the underlying mechanisms between these variables, which allow estimating the direct and indirect effects, including the possible mediational relationships in causal models of path analysis.

Method: the study had a sample of 918 Ecuadorian university students from three places of origin.

Results: The causal path analysis model indicates a significant and positive association between the variables depending on the place of origin of the participants. Likewise, the model obtained an adequate goodness of fit and good predictive capacity.

Conclusions: The data suggest that the model of underlying relationships between the study variables for the risk of ED, anorexia nervosa and bulimia nervosa, is different depending on the place of origin. It is indicated for future studies to estimate the criterion in the clinical population and with repetitive measures over time. We believe that the study will provide a starting point in the design, implementation and evaluation of prevention programs for eating disorders at the primary action levels.

\section{Plain English Summary}

It is known that there are associations between anorexia and bulimia nervosa with: anxiety, depression, perfectionism, emotional dysregulation, gender and place of origin. However, there is no information on these associations using trail analysis models, which allow estimating the direct and indirect effects. Therefore, this study had a sample of 918 Ecuadorian university students from three places of origin. The results indicate that the model has a good predictive capacity and is different according to the place of origin of the participants. Future studies are encouraged to evaluate the model in a clinical population and with repetitive measures over time. We believe that the study will provide support in prevention programs for eating disorders.

\section{Introduction}

Anorexia nervosa (AN) is classified within eating disorders (ED) and it is defined by the restriction of food intake, producing a marked decrease in weight (which reaches values below the minimum expected by sex and age), and it is accompanied by a permanent fear of increasing weight and persistent concerns about body image (American Psychiatric Association, APA, 2013). Bulimia nervosa (BN) is also included within the eating disorders group, and characterized by repeated episodes of excessive intake that occur in a short period of time (binges) and are accompanied by control behaviors weight (usually vomiting, fasting, intense exercise, use of laxatives and/or diuretics). BN shares the same dysfunctional concerns that AN about image and weight (recurrent feelings of body dissatisfaction and fear of gaining weight appear), but BN patients usually present weight into the normal range (APA, 2013). Both AN and BN disorders profiles show significant psychosocial impairment and severe medical complications (both physical and psychological), which can lead to an increased risk of suicide (Arcelus et al., 2011; Jenkins et al., 2011). 
The prevalence of eating disorders varies depending on the geographic areas. In Europe, the rates obtained in cross-sectional studies for AN are between 1\% and 4\%, while for BN are into the range 1-2\% (Keski-Rahkonen \& Mustelin, 2016). In North America, the presence of AN is identified in the general population between $1 \%$ and $4.2 \%$ (APA, 2006) and between $0.5 \%$ and $1.0 \%$ for BN (NICE, 2004). In South America, epidemiological data is more imprecise, largely as a consequence of empirical studies (Mérida-Pérez \& López-Hartmann, 2013): studies carried out in Argentina have published incidences between 2 and $8 \%$ for AN and BN; in Colombia around 2\% (Colombo, 2006); and in Bolivia around 2.6\% for AN and 4.7\% for BN (Freudental, 2000). However, it should be clarified that many of the published studies are carried out in high-risk populations formed mainly by young women, which could be overestimating the real prevalence in the general population.

Anxiety problems are frequently comorbid with ED (Brytek-Matera, 2008; Solano \& Cano, 2012; Swinbourne et al., 2012). Bulik (2002) noted that women with AN usually present anxiety symptoms related to the body weight and also to food behaviors. One of the anxiety disorders with the highest concurrence with AN is generalized anxiety disorder (Godier \& Park, 2015; Woodside \& Staab, 2006; Godart et al., 2003; Bulik, 2002). Furthermore, it has been observed that anxiety is not only a concurrent-comorbid state with eating disorders (Egan et al., 2013; Becker, DeViva \& Zayfert, 2004), but also a mediating link with the high perfectionism trait that usually characterizes AN and BN patients (Egan et al., 2013; Rivière \& Douilliez, 2017). For example, the Fairburn, Cooper \& Shafran (2003) model indicates that perfectionism is a maintenance mechanism of eating disorders, which, modulated by anxiety levels, acts as a risk factor for an overestimation of diet as a determining factor of body composition and weight. On the other hand, empirical research focused on the psychological factors involved in the factors related with the progression and maintenance of eating disorders have also point to the important role of anxiety, which seem achieve a relevant role in the prevention and treatment programs (Rivière \& Douilliez, 2017). In population-based samples, Montenegro, Blanco, Almengor \& Pereira (2009) have observed the presence of a positive correlation between high levels of anxiety and greater severity of the eating disorders (concretely, in university students from Costa Rica). Other research carried out with Mexican university students found that anxiety components are crucial for the onset and the course of AN, but not for BN (within the BN condition, the contribution of anxiety is interacting with sex and with age of menarche) (Pineda-García et al., 2014). Finally, Unikel et al. (2010) observed that the presence and the way in which the risk factors for eating disorders (including anxiety) largely depend on the geographical areas.

Comorbidity studies in the eating disorders area have also identified the important role of mood symptoms for the presence and progression of both AN and BN (Hudson et al., 2007; Kaye et al., 2004), mainly depression (Tseng \& Hu, 2012; Fischer et al., 2008), but also negative emotional states (Engel et al., 2005; Waller et al., 2003; Allen et al., 1998; Stice et al., al., 1996). In particular, it has been documented that AN and BN patients show high levels of depression compared with control samples without ED symptoms (Pyle et al., 1981; Bora \& Köse, 2016; Franko et al., 2018; Hudson et al., 1987; Johnson \& Larson, 1982; Kaye et al., 1986; Keck et al., 1990; Laessle et al., 1987; Lavender et al., 2015).

A current research is focused on the analysis of the emotional regulation capacities in patients with eating disorder (Claudat \& Lavender, 2018; Donahue et al., 2018; Mallorquí-Bagué et al., 2017; Pisetsky et al., 2017). This construct refers to the ability of people to identify and manage emotions appropriately, which implies having the necessary skills to relate emotions, cognition and behavior (Lavender et al., 2015). Functional emotional regulation involves being able to express emotions appropriately, regulating emotions and feelings appropriately to the contextual demands, having adequate coping skills, and being able to generate positive 
emotions. It has been observed that different forms and levels of emotional dysregulation predict the onset and the progression of several psychopathological conditions (Aldao et al., 2010), including eating disorders (Aldao et al., 2010; Gratz \& Roemer, 2004; Haynos \& Fruzzetti, 2011; Lavender et al., 2015; Mennin \& Fresco, 2009; Selby, Anestis, \& Joiner, 2008). Concretely, patients with AN show difficulty both in recognition and regulation of their emotions (Harrison et al., 2009), and in some cases these correlates are also related with the presence of alexithymia (Westwood et al., 2017). On the other hand, patients with BN have showed compulsive episodes associated with difficulties in controlling impulsivity, which are also worse in the presence of positive and/or negative emotional states (Bongers et al., 2013; Leehr et al., 2015). BN patients have also showed that negative mood states related with impairing emotional regulation frequently precede binges (Gianini et al., 2015; Nicholls et al., 2016).

\section{Objectives}

In summary, empirical studies evidence the relationships between AN and BN with psychopathological constructs such as anxiety, depression, perfectionism and emotional regulation. However, to our knowledge no studies have analyzed the underlying mechanisms/processes of these variables through models testing direct and indirect effects.

The present research aims to explore the associations between perfectionism, emotional dysregulation, anxiety, depression, sex and geographical origin with the AN and BN severity, through path analysis implemented with structural equations models.

\section{Method}

\section{Participants}

The sample included $n=918$ university students from Ecuador, resident in three cities of the country: Cuenca, Quito and Guayaquil. The participants were contacted through the institutional e-mail, and they were informed regarding the voluntary collaboration in the study.

The sample included three groups: $n=302$ participants from the Catholic University of Cuenca; $n=306$ participants from the Pontifical Catholic University of Ecuador in Quito, and $n=310$ participants from the University of Guayaquil. The mean age was 21.34 years $(S D=2.74)$.

\section{Instruments}

Risk Factors Associated with Eating Disorders Scale (Gómez-Peresmitré \& Ávila, 1998). This questionnaire explores the eating behavior styles and it screens for the high risk of eating disorders. Items are coded in a 5points Likert-scale (from 1 "never" to 5 "always"). The questionnaire includes seven dimensions: bulimia nervosa, anorexia nervosa, normal eating behavior, external food control attribution, psychological compensation, chronic and restrictive diet, and attribution factor. The sum of the scores within each subscale is interpreted as the severity on the correspondent dimension, as well as the potential risk of suffering of an eating disorder. The bulimia nervosa and the anorexia nervosa scores were used in this study, as measures of the symptom levels of each condition. In our sample, the internal consistency was very good, with values of Cronbach-alpha $a=0.90$ for $\mathrm{BN}$ and $\mathrm{a}=0.84$ for AN. 
Goldberg Anxiety and Depression Scale (GADS) (Goldberg et al., 1988). Self-report screen tool for the severity of the anxiety and depression level. It contains 18 items coded with a binary-response option (no-yes), grouped in two scales. The questionnaire has obtained adequate psychometrical evidence (Goldberg et al., 1988), also in the Ecuadorian adaptation (Reivan-Ortiz et al., 2019). In the sample of the sutyd, internal consistency was $a=0.74$ for anxiety and $a=0.76$ for depression.

Multidimensional Perfectionism Scale MPS (Frost et al., 1990). This questionnaire assesses perfectionism as a multidimensional construct, through 35 items coded with 5-point Likert-scale (from strongly disagree to strongly agree). Items are grouped into six factors (personal standards, concern over mistakes, doubts about actions, parental expectations, parental criticism, and organization), and a total score is also obtained as the sum of all the items. Studies have provided evidence regarding its psychometric properties (Frost et al., 1990). In this work, the global scale obtained an excellent consistency, $a=.89$.

Difficulties in Emotion Regulation Scale DERS (Gratz \& Roemer, 2004). Self-report questionnaire aimed to assess difficulties in the emotional regulation. It includes 36 items coded in a 5-point Likert-scale (from never or almost never to always or almost always), grouped in five primary factors: non-acceptance of emotional responses, difficulty engaging in goal-directed behavior, impulse control difficulties, lack of emotional awareness, limited access to emotion regulation strategies, and lack of emotional clarity. A total score is also available as the sum of all subscales. The Ecuadorian adaptation of the tool achieved adequate psychometric properties (ReivanOrtiz et al., 2020). In this work, internal consistency for the global score was excellent, a=0.91.

\section{Procedure}

The study obtained the approval of the Ethic Committee of the Catholic University of Ecuador, and it was carried out according to the guiding statements in the Declaration of Helsinki for health-medical research in humans.

All the participants provided signed consent, and were informed of the objectives of the research. It was guaranteed that all the data would be managed with absolute confidentiality, according to the APA's Ethical Principles of Psychologists and Code of Conduct (APA, 2002, 2008). Participants get no monetary compensation for their collaboration.

\section{Statistical analysis}

Statistical analysis was carried out with Stata15 for windows. Path analysis was implemented through structural equation modeling (SEM). This procedure is an extension of multiple regressions with the aim to model direct and indirect (mediational) effects (Kline, 2005). The procedure can be used for exploratory and confirmatory analyses, and therefore it is useful for testing and developing theories (MacCallum \& Austin, 2000). In this work, SEM was conducted with the maximum likelihood estimation parameter, defining a multi-group model to assess the invariance of the structural coefficients based on the geographical origin of the subsamples. Goodness-of-fit was tested with the usual indexes: chi-square test $\left(X^{2}\right)$, Root Mean Square Error of Approximation (RMSEA), Bentler's Comparative Fit Index (CFI), Tucker-Lewis Index (TLI) and Standardized Root Mean Square Residual (SRMR). It was considered adequate fitting for (Barret, 2007): non-significant result in the $X^{2}$ test, RMSEA $<0.08, T L I>0.90, C F I>0.90$ and SRMR $<0.10$. The global predictive capacity for the fitted model was valued with the coefficient of determination (CD). 


\section{Results}

\section{Characteristics of the sample}

Table 1 displays the sociodemographic description of the sample, and the comparison between the groups (Cuenca, Quito and Guayaquil). The groups presented differences for sex (lower proportion of women in Quito), employment status (higher proportion of employed participants in Quito), education levels (higher proportion of participants within initial cycles in Cuenca) and age (younger participants in Cuenca). No differences by marital status emerged.

\section{Path Analysis}

SEM achieved adequate fitting: $\chi^{2}=6.33(p=.097), \mathrm{RMSEA}=0.06, \mathrm{CFI}=0.997, \mathrm{TLI}=0.945$, and SRMR=0.015. Global predictive capacity was around $30 \%(C D=0.284)$. The global invariance test showed significant results, $\left(X^{2}=65.99, p<.001\right)$, suggesting that the underlying processes are different depending on the geographic area. Figure 1 shows the path-diagram with the standardized coefficients, stratified by the city. Continuous lines represent significant coefficients ( $p>0.05)$, while dash lines represent non-significant coefficients $(p>0.05)$. Table S1 (supplementary material) contains the complete results for the model.

For Cuenca (first path-diagram of Figure 1), it was observed that AN severity was higher for subjects with higher scores in perfectionism and emotional dysregulation (these two effects constituted direct effects). On the other hand, the BN severity was directly related to higher levels of perfectionism and emotional dysregulation, and also to higher depressive symptoms level. For BN, an indirect relationship was obtained through the mediation role of the depressive levels: the higher values in depression are reported by women and by patients with higher scores in perfectionism and emotional dysregulation, and higher depressive symptoms levels increased BN levels (that is, depression is a mediating variable in the path between sex, perfectionism, and emotional dysregulation with $\mathrm{BN}$ ). Other indirect effect for $\mathrm{BN}$ was obtained through the mediation role of emotional dysregulation: higher scores in emotional dysregulation were related to higher perfectionism levels (that is, emotional dysregulation is a mediating variable in the relationships of perfectionism with $\mathrm{BN}$ ).

For Quito (second path-diagram of Figure 1), it was observed higher AN level among individuals with a higher perfectionism and depression scores (these associations constitute direct effects). BN severity was directly related to higher emotional dysregulation and depressive symptoms levels, as well as with male gender. For AN and $\mathrm{BN}$, indirect effects were obtained through the mediation role of the depressive score: the higher values in depression were obtained for women and patients with higher perfectionism and emotional dysregulation, and higher depressive symptoms increased AN and BN levels (depression was a mediational variable in the path between sex, perfectionism and emotional dysregulation, with AN and BN). Other indirect effect was obtained, being emotional dysregulation a mediational variable: the higher values in emotional dysregulation were obtained for patients with higher perfectionism levels (emotional dysregulation is a mediational variable in the path between perfectionism with $\mathrm{AN}$ and $\mathrm{BN}$ ).

For Guayaquil (third path-diagram of Figure 1), it was observed that AN severity was higher for female sex, and those with higher perfectionism and emotional dysregulation levels (these were direct effects). The BN severity was directly related to the male sex and higher emotional dysregulation levels. For AN and BN indirect effects also were found, through the mediational role of emotional dysregulation: higher values in emotional 
dysregulation were obtained in patients with higher perfectionism scores (emotional dysregulation was a mediational variable in the path between perfectionism with $\mathrm{AN}$ and $\mathrm{BN}$ ).

\section{Discussion}

The present study aimed to analyze the underlying mechanisms of AN and BN levels through path analysis, which measured the direct and indirect effects (mediational links) between emotional regulation, perfectionism, anxiety, depression, sex and geographical area (Cuenca, Quito and Guayaquil), in a large sample of Ecuadorian university students. The main results showed that the city obtained significant results in the invariance test, suggesting that the relationships patterns depended on the city.

The results regarding the differences in the structural coefficients depending on the region of origin are consistent with other investigations (Pineda-García et al., 2017; Pineda-García et al., 2014; Unikel et al., 2010), which implies that the etiological study of AN and BN must be carried out specifically according to the geographical areas (even within the same country).

The AN and BN levels were not directly influenced by the anxiety scores in the three cities, despite high anxiety was frequently related to the presence and severity in ED patients (Brytek-Matera, 2008), concretely among AN (Bulik, 2002; Godier \& Park, 2015; Woodside \& Staab, 2006; Godart et al., 2003). It should be noted that in two cities (Cuenca and Quito) women showed higher scores in the anxiety measure, which can also suggest that female sex could show higher concerns about food without being necessarily concerns about weight (Bulik, 2002).

On the other hand, this study evidenced that depression was associated with higher AN and BN levels in Quito, and with higher BN levels in Cuenca. This is consistent with previous results (Tseng \& Hu, 2012; Fischer et al., 2008), which suggest that $A N$ and $B N$ are characterized by negative emotion states, such as depressive symptoms and general/specific negative affective states (Engel et al., 2005; Waller et al., 2003; Allen, Scannell \& Turner, 1998; Stice et al., 1996).

Emotional dysregulation was associated with higher AN and BN levels in Cuenca and Guayaquil, and only with BN levels in Quito. This result reinforces previous studies which indicate the central role of this construct for eating disorders (Gratz \& Roemer, 2004, Haynos \& Fruzzetti, 2011; Wildes \& Marcus, 2011), particularly for the onset and progression of AN and BN (Lavender et al., 2015). The observation of the predictive contribution of perfectionism on the emotional dysregulation levels, and the contribution of this phenotype on the AN and BN levels also reinforce the relevance of perfectionism as a central key within the eating disorders spectrum (Bruch, 1978; Franco Paredes et al., 2005; Milos et al., 2004; Moor et al., 2004; Moreno, 2018; Scappatura et al., 2017; Badenes-Sastre et al., 2016; Pratt et al., 2001; Rodríguez et al., 2016; Rutsztein et al., 2014; Rutsztein et al., 2013; Vitousek \& Manke, 1994). In our study, perfectionism directly contribute on the AN scores, and in the Cuenca city it also achieved an impact on the BN levels. Regarding the indirect effects, the contribution of perfectionism on the AN level was mediated by the emotional dysregulation and the depression levels within participants in Quito, and only by emotional dysregulation among participants in Cuenca and Guayaquil. On the other hand, the indirect effect of perfectionism on the BN levels was mediated by emotional dysregulation and depression in Cuenca and Quito, while it was only mediated by emotional dysregulation in Guayaquil. This result also 
reinforces evidences obtained in previous studies, which suggest that perfectionism is a process implied in the onset and maintenance of the eating disorders (Rivière \& Douilliez, 2017; Fairburn et al., 2003).

This study should be interpreted according to a set of limitations. First, the sample included difference proportion of men and women, which should be taken into account when generalizing the results. On the other hand, screening tools were used for assessing the presence of AN and BN symptom levels, which did not allow to assess the clinical presence of the AN and BN disorders. Finally, cross-sectional data was analyzed, which limited the capacity to assess the longitudinal processes between the variables.

Two main strengths should be highlighted: the sample composition (size and precedence), and the statistical approach. The sample included university students, which represent a group with high vulnerability for the onset and progression of eating disorders (cultural and social stereotypes about the figure and body image have high impact on this group). In addition, the large sample size and the inclusion of participants from the biggest cities in Ecuador provides of high external validity to the study. Regarding path analysis, there are several advantages for this method in the psychological research: it allows examine multiple direct and indirect effects (including mediational relationships), and it provides a very useful graphical representation (it helps to make dependencies between variables visible and clear).

The raising prevalence of eating disorders among university students makes necessary empirical evidence regarding the underlying mechanisms explaining the onset and progression of these complex clinical processes. To the best of our knowledge, his is the first study exploring the role of sex, age, perfectionism, emotional regulation, anxiety and depression in the AN and BN levels. The evidence that the relationships-paths are different depending on the geographic areas should be taken into account for the development of prevention and treatment plans. Currently, many intervention systems used in Ecuador were initially developed for patients living in other countries (mainly United States and/or European countries), and therefore there is no evidence regarding the efficiency for patients with other clinical profiles. Our results should contribute to the development of new prevention and treatment approaches, focused on the specific needs of individuals in South America.

\section{Conclusions}

The mechanisms that influence the risk of suffering from the disorder of anorexia and bulimia nervosa are mediated by the psychopathological severity of anxiety, emotional regulation, depression and perfectionism, through a different causal model of underlying relationships in each place of origin. The female gender is a biological characteristic that prevails the risk of the disorder in the three places evaluated.

\section{Abbreviations}

AN: Anorexia nervosa; BN: Bulimia nervosa; ED: Eating disorder; RMSEA: Root Mean Square Error of Approximation; CFI: Comparative Fit Index; TLI: Tucker-Lewis Index; SRMR: Standarized Root Mean-Square.

\section{Declarations}

\section{Acknowledgments}


We wish to thank our research assistants (Edwin Maxi and Jordy Chamba) and the coordination of the Basic Psychology, Behavioral Analysis and Program Development Laboratory of the Catholic University of Cuenca.

\section{Authors 'contributions}

GGRO was responsible for the study design, data collection, and descriptive data analysis. RGP was responsible for the literature review and performed the path analysis. PEOR contributed to the analysis and discussion of the findings. The authors read and approved the final manuscript.

\section{Funding}

No funding.

\section{Availability of data and materials}

Please contact GGRO for data request.

\section{Ethical approval and consent to participate}

The research project was approved by the Research Ethics Committee of the Catholic University of Cuenca (PoINV-R00765: reference 2020). All participants in the Quito, Guayaquil and Cuenca University groups received verbal and written information about the research project and signed a consent form. They were also informed that they could withdraw from the study at any time. The data was treated confidentially and anonymized.

\section{Consent for publication}

Not applicable.

\section{Competing interests}

The authors declare that they have no competing interests.

\section{References}

1. Agras, W. (2009). Treatment of eating disorders. En A. F. Schatzberg y C. B. Nemeroff (Eds.), The American psychiatric publishing textbook of psychopharmacology, 1231-2140.

2. Aldao, A., Nolen-Hoeksema, S., \& Schweizer, S. (2010). Emotion-regulation strategies across psychopathology: A meta-analytic review. Clinical Psychology Review, 30, 217-237. http://dx.doi.org/10.1016/j.cpr.2009.11.004.

3. Aldao, A., Nolen-Hoeksema, S., \& Schweizer, S. (2010). Emotionregulation strategies across psychopathology: A meta-analytic review. Clinical Psychology Review, 30(2), 217-237. https://doi.org/ 10.1016/j.cpr.2009.11.004.

4. Allen, C.L., Scannell, E.D., \& Turner, H.R. (1998). Guilt and hostility as coexisting characteristics of bulimia nervosa. Australian Psychologist, 33, 143-147. http://dx.doi.org/10. 1080/00050069808257396.

5. American Psychiatric Association (2006). Practice guidelíne for the treatment ofpatients with eating disorders. 3rd ed. Washington (DC): American Psychiatric Association. 
6. American Psychiatric Association (2013). Diagnostic and statistical manual of mental disorders (5th ed.). Washington, DC: Author.

7. Arcelus, J., Mitchell, A.J., Wales, J., \& Nielsen, S. (2011). Mortality rates in patients with anorexia nervosa and other eating disorders. A meta-analysis of 36 studies. Archives of General Psychiatry, 68, 724-731. http://dx.doi.org/10.1001/archgenpsychiatry. 2011.74.

8. Badenes-Sastre, M., Navarro Haro, M. V., \& García-Palacios, A. (2016). Estrategias en la regulación emocional en la comorbilidad entre el trastorno límite de la personalidad y los trastornos alimentarios.

9. Bardone-Cone, A. M., Wonderlich, S. A., Frost, R. O., Bulik, C. M., Mitchell, J. E., Uppala, S., \& Simonich, H. (2007). Perfectionism and eating disorders: Current status and future directions. Clinical Psychology Review, 27(3), 384-405http://dx.doi.org/10.1016/j.cpr. 2006.12.005.

10. Barrett, P. (2007). Structural Equation Modelling: Adjudging Model Fit. Personality and Individual Differences, 42 (5), 815-24. doi:10.1016/j.paid.2006.09.018

11. Becker, C., DeViva, J. \& Zayfert, C. (2004). Eating disorder symptoms among female anxiety disorder patients in clinical practice: The importance of anxiety comorbidity assessment. Journal of Anxiety Disorders, 18(3), 255-274.

12. Bongers, P., Jansen, A., Houben, K., \& Roefs, A. (2013). Happy eating: The single target implicit association test predicts overeating after positive emotions. Eating Behaviors, 14(3), 348-355. https:// doi.org/10.1016/j.eatbeh.2013.06.007

13. Boone, L., Claes, L., \& Luyten, P. (2014). Too strict or too loose? Perfectionism and impulsivity: The relation with eating disorder symptoms using a person-centered approach. Eating Behaviors, 15(1), 1723http://dx.doi.org/10.1016/j.eatbeh.2013.10. 013.

14. Boone, L., Soenens, B., \& Braet, C. (2011). Perfectionism, body dissatisfaction, and bulimic symptoms: The intervening role of perceived pressure to be thin and thin ideal internalization. Journal of Social and Clinical Psychology, 30(10), 1043http://dx.doi.org/10. 1521/jscp.2011.30.10.1043.

15. Bora, E., \& Köse, S. (2016). Meta-analysis of theory of mind in anorexia nervosa and bulimia nervosa: A specific İmpairment of cognitive perspective taking in anorexia nervosa?. International Journal of Eating Disorders, 49(8), 739-740.

16. Brytek-Matera, A. (2008). Mood and emotional symptoms in eating disordered patients. Archives of Psychiatry and Psychotherapy, 2(10), 65-71.

17. Bulik, C. M. (2002). Anxiety, depression and eating disorders. En C. Fairburn y K. Brownell (Eds.), Eating disorders and obesity (pp. 193-199). New York: Guilford Press.

18. Bulik, C. M., Tozzi, F., Anderson, C., Mazzeo, S. E., Aggen, S., \& Sullivan, P. F. (2003). The relation between eating disorders and components of perfectionism. American Journal of Psychiatry, 160(2), 366368https://dx.doi.org/10.1176/appi.ajp.160.2.366.

19. Burns, D. D. (1980). The perfectionist's script for self-defeat. Psychology Today, 14(6), 34-52.

20. Claes, L., Vandereycken, W., Vandeputte, A. \& Braet, C. (2013). Personality subtypes in female pre-bariatric obese patients: Do they differ in eating disorder symptoms, psychological complaints and coping behavior? European Eating Disorders Review, 21(1), 72-77.

21. Claudat, K., \& Lavender, J. M. (2018). An introduction to the special issue on emotion regulation and eating disorders. Eating disorders, 26(1), 1-4. 
22. Colombo, J. L. (2006). "Comer todo o comer nada". (1ºdición) Buenos Aires, México: Lumen SRL.

23. Cox, B. J., Enns, M. W., \& Clara, I. P. (2002). The multidimensional structure of perfectionism in clinically distressed and college student samples. Psychological Assessment, 14(3), 365https://dx.doi.org/10.1037//1040-3590.14.3.365.

24. Donahue, J. M., Reilly, E. E., Anderson, L. M., Scharmer, C., \& Anderson, D. A. (2018). Evaluating Associations Between Perfectionism, Emotion Regulation, and Eating Disorder Symptoms in a Mixed-Gender Sample. The Journal of nervous and mental disease, 206(11), 900-904.

25. Egan, S., Watson, H., Kane, R., McEvoy, P., Fursland, A. \& Nathan, P. (2013). Anxiety as a mediator between perfectionism and eating disorders. Cognitive Therapy and Research, 37(5), 905-913.

26. Engel, S., Wonderlich, S., Crosby, R., Wright, T., Mitchell, J., Crow, S., et al. (2005). A study of patients with anorexia nervosa using ecologic momentary assessment. International Journal of Eating Disorders, 38, 335-339. http://dx.doi.org/10.1002/eat. 20184.

27. Fairburn, C. G., Cooper, Z., \& Shafran, R. (2003). Cognitive behaviour therapy for eating disorders: A "transdiagnostic" theory and treatment. Behaviour Research and Therapy, 41(5), 509528https://dx.doi.org/10.1016/s0005-7967(02)00088-8.

28. Fischer, S., Smith, G. T. \& Cyders, M. A. (2008). Another look at impulsivity: A meta-analytic review comparing specific dispositions to rash action in their relationship to bulimic symptoms. Clinical Psychology Review, 28(8), 1413-1425.

29. Franko, D. L., Tabri, N., Keshaviah, A., Murray, H. B., Herzog, D. B., Thomas, J. J., ... \& Eddy, K. T. (2018). Predictors of long-term recovery in anorexia nervosa and bulimia nervosa: Data from a 22-year longitudinal study. Journal of psychiatric research, 96, 183-188.

30. Freudenthal, A. (2000), Prevalencia de los síntomas asociados con los trastornos de la conducta alimentaria en adolescentes escolarizadas de 16 a 18 años, en la zona sur de La Paz, Tesis de grado Universidad Mayor de San Andrés

31. Frost, R. O., Heimberg, R. G., Holt, C. S., Mattia, J. I., \& Neubauer, A. L. (1993). A comparison of two measures of perfectionism. Personality and Individual Differences, 14(1), 119-126https://dx.doi.org/10.1016/01918869(93)90181-2.

32. Frost, R. O., Marten, P., Lahart, C., \& Rosenblate, R. (1990). The dimensions of perfectionism. Cognitive therapy and research, 14(5), 449-468.

33. Gianini, L. M., White, M. A., \& Masheb, R. M. (2013). Eating pathology, emotion regulation, and emotional overeating in obese adults with binge eating disorder. Eating Behaviors, 14(3), 309-313. https://doi.org/10.1016/j.eatbeh.2013.05.008.

34. Godart, N. T., Flament, M. F., Curt, F., Perdereau, F., Lang, F., Venisse, J. L. \& Jeammet, P. (2003). Anxiety disorders in subjects seeking treatment for eating disorders: a DSM-IV controlled study. Psychiatry research, 117(3), 245-258.

35. Godier, R. \& Park, R. (2015). A novel measure of compulsive food restriction in anorexia nervosa: Validation of the Self-Starvation Scale (SS). Eating Disorders Review, 26(3), 10-13.

36. Goldberg, D., Bridges, K., Duncan-Jones, P., \& Grayson, D. (1988). Detecting anxiety and depression in general medical settings. Bmj, 297(6653), 897-899. 
37. Gómez-Peresmitré, G. \& Ávila, A. E. (1998). Conducta alimentaria y obesidad. Revista Iberoamericana de Psicología, 6(2), 10-22.

38. Gratz, K. L., \& Roemer, L. (2004). Multidimensional assessment of emotion regulation and dysregulation: Development, factor structure, and initial validation of the difficulties in emotion regulation scale. Journal of psychopathology and behavioral assessment, 26(1), 41-54.

39. Harrison, A., Sullivan, S., Tchanturia, K., \& Treasure, J. (2009). Emotion recognition and regulation in anorexia nervosa. Clinical Psychology \& Psychotherapy, 16(4), 348-356. https://doi.org/ 10.1002/cpp.628.

40. Haynos, A.F., \& Fruzzetti, A.E. (2011). Anorexia nervosa as a disorder of emotion dysregulation: Evidence and treatment implications. Clinical Psychology: Science and Practice, 18, 183-202. http://dx.doi.org/10.1111/j.1468-2850.2011.01250.x.

41. Hudson, J. I., \& Pope, H. (1987). Depression and eating disorders. In 0. Cameron (Ed.), Presentations of depression (pp. XXX-XXX). New York: John Wiley and Sons.

42. Hudson, J.I., Hiripi, E., Pope, H.G., \& Kessler, R.C. (2007). The prevalence and correlates of eating disorders in the National Comorbidity Survey Replication. Biological Psychiatry, 61, 348-358.

http://dx.doi.org/10.1016/j.biopsych.2006.03.040.

43. Jenkins, P.E., Rienecke Hoste, R., Meyer, C., \& Blissett, J.M. (2011). Eating disorders and quality of life: A review of the literature. Clinical Psychology Review, 31, 113-121.

http://dx.doi.org/10.1016/j.cpr.2010.08.003

44. Johnson, C., \& Larson, R. (1982). Bulimia: An analysis of moods and behaviors. Psychosomatic Medicine, 44, 341-351

45. Kaye, W. H., Gwirtsman, D. T., George, S. R., Weiss, and Jimerson, D. C. (1986). Relationships of mood alterations to bingeing behavior in bulimia. British Journal of Psychiatry, 149, 479-485.

46. Kaye, W.H., Bulik, C.M., Thorton, L., Barbarich, N., \& Masters, K. (2004). Comorbidity of anxiety disorders with anorexia nervosa. American Journal of Psychiatry, 161, 2215-2221.

http://dx.doi.org/10.1176/appi.ajp.161.12.2215.

47. Keck, P. E., Pope, H. G., Hudson, J. I., et al. (1990). A controlled study of phenomenology and family history in outpatients with bulimia nervosa. Comprehensive Psychiatry, 31, 275-283.

48. Keski-Rahkonen, A., \& Mustelin, L. (2016). Epidemiology of eating disorders in Europe: prevalence, incidence, comorbidity, course, consequences, and risk factors. Current opinion in psychiatry, 29(6), 340-345.

49. Kline, R.B. (2005). Principles and Practice of Structural Equation Modeling (2nd Edition ed.). New York: The Guilford Press.

50. Laessle, R. G., Kittl, S., Fichter, M. M., et al. (1987). Major affective disorder in anorexia nervosa and bulimia. British Journal of Psychiatry, 152, 785-789.

51. Lavender, J. M., Wonderlich, S. A., Engel, S. G., Gordon, K. H., Kaye, W. H., \& Mitchell, J. E. (2015). Dimensions of emotion dysregulation in anorexia nervosa and bulimia nervosa: A conceptual review of the empirical literature. Clinical psychology review, 40, 111-122.

52. Lavender, J. M., Wonderlich, S. A., Engel, S. G., Gordon, K. H., Kaye, W. H., \& Mitchell, J. E. (2015). Dimensions of emotion dysregulation in anorexia nervosa and bulimia nervosa: A conceptual review of the empirical literature. Clinical psychology review, 40, 111-122. 
53. Leehr, E. J., Krohmer, K., Schag, K., Dresler, T., Zipfel, S., \& Giel, K. E. (2015). Emotion regulation model in binge eating disorder and obesity - A systematic review. Neuroscience \& Biobehavioral Reviews, 49, 125134. https://doi.org/10.1016/j. neubiorev.2014.12.008.

54. Loehlin, J. C., \& Beaujean, A. A. (2016). Latent variable models: An introduction to factor, path, and structural equation analysis. Taylor \& Francis.

55. MacCallum, R.C., \& Austin, J.T. (2000). Applications of structural equation modeling in psychological research. Annual Review of Psychology, 51, 201-226

56. Mallorquí-Bagué, N., Vintró-Alcaraz, C., Sánchez, I., Riesco, N., Agüera, Z., Granero, R., ... Fernández-Aranda, F. (2017). Emotion Regulation as a Transdiagnostic Feature Among Eating Disorders: Cross-sectional and Longitudinal Approach. European Eating Disorders Review, 26(1), 53-61. doi:10.1002/erv.2570

57. Mennin, D.S., \& Fresco, D.M. (2009). Emotion regulation as an integrative framework for understanding and treating psychopathology. In A.M. Kring, \& D.M. Sloan (Eds.), Emotion regulation and psychopathology: A transdiagnostic approach to etiology and treatment (pp. 356-379). New York: Guilford Press.

58. Mérida Pérez, C., \& López Hartmann, R. (2013). Prevalencia de los trastornos de la conducta alimentaria y su relación con la ansiedad y depresión en adolescentes de secundaria de la ciudad de La Paz. Revista de Investigacion Psicologica, (10), 69-85.

59. Montenegro, E., Blanco, T., Almengor, P. \& Pereira, C. (2009). Trastornos alimenticios, ansiedad y depresión en una muestra de estudiantes de psicología de la Universidad de Costa Rica. Revista Wimblu, 4(1), 31-40.

60. Montero-Rojas, E. M. (2008). Escalas o Índices para la medición de constructos: El dilema del analista de datos. Avances en medición, 6, 15-24.

61. Moreno, J. A. B. (2018). Una mirada al estilo de personalidad tendiente a los desórdenes alimentarios desde el constructivismo hermenéutico. Poiésis, 1(34), 73-87.

62. National Institute for Clinical Excellence (NI CE). Eating disorders. Core inlerventions in the treatment and management of anorexia nervosa, bulimia nen,osa and relaied eating disorders. National Collaborating Centre for Mental Health. Leicester 1 London: The British Psychological Society. The Royal College of Psychiatrists; 2004

63. Nicholls, W., Devonport, T. J., \& Blake, M. (2016). The association between emotions and eating behaviour in an obese population with binge eating disorder. Obesity Reviews, 17(1), 30-42.

https://doi.org/10.1111/obr.12329.

64. Organización Mundial de la Salud (1986). Primera conferencia internacional sobre promoción de la salud: Iniciativa en pro de una nueva acción de salud pública. Disponible en:

http://www.promocion.salud.gob.mx/dgps/descargas1/ promocion/2 carta de ottawa.pdf

65. Pineda-García, G., Gómez-Peresmitré, G., Platas Acevedo, S., \& Velasco Ariza, V. (2017). Ansiedad como predictor del riesgo de anorexia y bulimia: Comparación entre universitarios de Baja California y Ciudad de México. Revista Mexicana de Trastornos Alimentarios, 8(1).

66. Pineda-García, G., Gómez-Peresmitré, G., Platas, S., Velasco, V. \& Arámburo, V. (2014). Riesgo de anorexia y bulimia en función de la ansiedad y edad de la pubertad en universitarios de Baja California-México. Revista Mexicana de Trastornos Alimentarios, 5(2), 80-90.

67. Pisetsky, E. M., Haynos, A. F., Lavender, J. M., Crow, S. J., \& Peterson, C. B. (2017). Associations between emotion regulation difficulties, eating disorder symptoms, non-suicidal self-injury, and suicide attempts in a 
heterogeneous eating disorder sample. Comprehensive psychiatry, 73, 143-150.

68. Pyle, R., Mitchell, J., Eckert, G., et al. (1981). The incidence of bulimia in freshman college students. International Journal of Eating Disorders, 2, 75-85.

69. Reivan-Ortiz, G. G., Ortiz Rodas, P. E., \& Reivan Ortiz, P. N. (2020). A Brief Version of the Difficulties in Emotion Regulation Scale (DERS): Validity Evidence in Ecuadorian Population. International Journal of Psychological Research, 13(2), 14-24.

70. Reivan-Ortiz, G., Pineda-Garcia, G., Parias, L., \& Darío, B. (2019). Psychometric Properties of The Goldberg Anxiety and Depression Scale (GADS) In Ecuadorian Population. International Journal of Psychological Research, 12(1), 41-48.

71. Rivière, J., \& Douilliez, C. (2017). Perfectionism, rumination, and gender are related to symptoms of eating disorders: A moderated mediation model. Personality and Individual Differences, 116, 63-68.

72. Rutsztein, G., Leonardelli, E., Scappatura, M. L., Murawski, B., Elizathe, L., \& Maglio, A. L. (2013). Propiedades psicométricas del Inventario de Trastornos Alimentarios-3 (EDI-3) en mujeres adolescentes de Argentina. Revista mexicana de trastornos alimentarios, 4(1), 1-14.

73. Rutsztein, G., Scappatura, M. L., \& Murawski, B. (2014). Perfeccionismo y baja autoestima a través del continuo de los trastornos alimentarios en adolescentes mujeres de Buenos Aires. Revista mexicana de trastornos alimentarios, 5(1), 39-49.

74. Scappatura, M. L., Bidacovich, G., Falivelli, B., Belén, M., \& Rutsztein, G. (2017). Dimensiones del perfeccionismo (adaptativo y desadaptativo) en adolescentes con trastorno de la conducta alimentaria. Revista mexicana de trastornos alimentarios, 8(2), 131-141.

75. Selby, E.A., Anestis, M.D., \& Joiner, T.E. (2008). Understanding the relationship between emotional and behavioral dysregulation: Emotional cascades. Behaviour Research and Therapy, 46, 593-611. http://dx.doi.org/10.1016/j.brat.2008.02.002.

76. Solano, N. \& Cano, A. (2012). Ansiedad en los trastornos alimentarios: Un estudio comparativo. Psicothema, 24(3), 384-389.

77. Stice, E., Nemeroff, C., \& Shaw, H.E. (1996). Test of the dual pathway model of bulimia nervosa: Evidence for dietary restraint and affect regulation mechanisms. Journal of Social and Clinical Psychology, 15, 340363. http://dx.doi.org/10.1521/jscp.1996.15.3. 340

78. Stice, E., Shaw, H. \& Nemeroff, C. (1998). Dual pathway model of bulimia nervosa: Longitudinal support for dietary restraint and affect regulation mechanisms. Journal of Social and Clinical Psychology, 17(2), 129149.

79. Striegel-Moore, R., Rosselli, F., Perrin, N., DeBar, L., Wilson, G. T., May, A., et al. (2009). Gender difference in the prevalence of eating disorder symptoms. International Journal of Eating Disorders, 42(5), 471-474.

80. Swinbourne, J., Hunt, C., Abbott, M., Russell, J., St Clare, T. \& Touyz, S. (2012). The comorbidity between eating disorders and anxiety disorders: Prevalence in an eating disorder sample and anxiety disorder sample. Australian and New Zealand Journal of Psychiatry, 46(2), 118-131.

81. Tabachnick, B. G., \& Fidell, L. S. (2013). Using multivariate statistics (6th ed.). Boston, MA: Allyn and Bacon.

82. Tseng, M. C. \& Hu, F. C. (2012). Latent class analysis of eating and impulsive behavioral symptoms in Taiwanese women with bulimia nervosa. Journal of Psychosomatic Research, 72(1), 65-72. 
83. Unikel, C., Nuño, B., Celis, A., Saucedo, T., Trujillo, E., García, F., et al. (2010). Conductas alimentarias de riesgo: Prevalencia en estudiantes mexicanas de 15 a 19 años. Revista de Investigación Clínica, 62(5), 424432.

84. Waller, G., Babbs, M., Milligan, R., Meyer, C., Ohanian, V., \& Leung, N. (2003). Anger and core beliefs in the eating disorders. International Journal of Eating Disorders, 34, 118-124. http://dx.doi.org/10.1002/eat.10163.

85. Westwood, H., Kerr-Gaffney, J., Stahl, D., \& Tchanturia, K. (2017). Alexithymia in eating disorders: Systematic review and metaanalyses of studies using the Toronto Alexithymia Scale. Journal of Psychosomatic Research, 99(June), 66-81. https://doi.org/ 10.1016/j.jpsychores.2017.06.007

86. Wildes, J.E., \& Marcus, M.D. (2011). Development of emotion acceptance behavior therapy for anorexia nervosa: A case series. International Journal of Eating Disorders, 44, 421-427. http://dx.doi.org/10.1002/eat.20826.

87. Woodside, B. \& Staab, R. (2006). Management of psychiatric comorbidity in anorexia nervosa. CNS Drugs, 20(8), 655-663.

\section{Tables}


Table 1

Description of the sample

\begin{tabular}{|c|c|c|c|c|c|c|c|c|c|c|}
\hline & & $\begin{array}{l}\text { Cuence } \\
n=302\end{array}$ & & $\begin{array}{l}\text { Quito } \\
n=306\end{array}$ & & $\begin{array}{l}\text { Guaya } \\
n=310\end{array}$ & & & & \\
\hline & & $n$ & $\%$ & $n$ & $\%$ & $n$ & $\%$ & $\chi^{2}$ & $d f$ & $p$ \\
\hline Sex & Women & 185 & 61.3 & 164 & 53.6 & 196 & 63.2 & 6.59 & 2 & $<.001$ \\
\hline & Men & 117 & 38.7 & 142 & 46.4 & 114 & 36.8 & & & \\
\hline Civil status & Single & 279 & 92.4 & 276 & 90.2 & 290 & 93.5 & 6.07 & 6 & .416 \\
\hline & Married & 16 & 5.3 & 24 & 7.8 & 18 & 5.8 & & & \\
\hline & Divorced & 6 & 2.0 & 4 & 1.3 & 2 & 0.6 & & & \\
\hline & Widow & 1 & 0.3 & 2 & 0.7 & 0 & 0 & & & \\
\hline Employment & Employed & 58 & 19.2 & 78 & 25.5 & 37 & 11.9 & 18.54 & 2 & $<.001$ \\
\hline & Unemployed & 244 & 80.8 & 228 & 74.5 & 273 & 88.1 & & & \\
\hline Education & $\begin{array}{l}\text { 1st } \\
\text { semester }\end{array}$ & 148 & 49.0 & 1 & 0.3 & 0 & 0 & 883.55 & 16 & $<.001$ \\
\hline & $\begin{array}{l}\text { 2nd } \\
\text { semester }\end{array}$ & 65 & 21.5 & 6 & 2.0 & 28 & 9.0 & & & \\
\hline & $\begin{array}{l}\text { 3th } \\
\text { semester }\end{array}$ & 89 & 29.5 & 42 & 13.7 & 41 & 13.2 & & & \\
\hline & $\begin{array}{l}\text { 4th } \\
\text { semester }\end{array}$ & 0 & 0 & 85 & 27.8 & 101 & 32.6 & & & \\
\hline & $\begin{array}{l}\text { 5th } \\
\text { semester }\end{array}$ & 0 & 0 & 75 & 24.5 & 5 & 1.6 & & & \\
\hline & $\begin{array}{l}\text { 6th } \\
\text { semester }\end{array}$ & 0 & 0 & 49 & 16.0 & 21 & 6.8 & & & \\
\hline & $\begin{array}{l}\text { 7th } \\
\text { semester }\end{array}$ & 0 & 0 & 43 & 14.1 & 17 & 5.5 & & & \\
\hline & $\begin{array}{l}\text { 8th } \\
\text { semester }\end{array}$ & 0 & 0 & 0 & 0 & 0 & 0 & & & \\
\hline & $\begin{array}{l}\text { 9th } \\
\text { semester }\end{array}$ & 0 & 0 & 3 & 1.0 & 3 & 1.0 & & & \\
\hline & $\begin{array}{l}\text { 10th } \\
\text { semester }\end{array}$ & 0 & 0 & 2 & 0.7 & 94 & 30.3 & & & \\
\hline & & Mean & SD & Mean & SD & Mean & SD & $F$ & $d f$ & $p$ \\
\hline Age (years) & & 20.27 & 2.53 & 21.99 & 2.49 & 21.74 & 2.88 & 37.423 & $2 / 916$ & $<.001$ \\
\hline
\end{tabular}


Figures

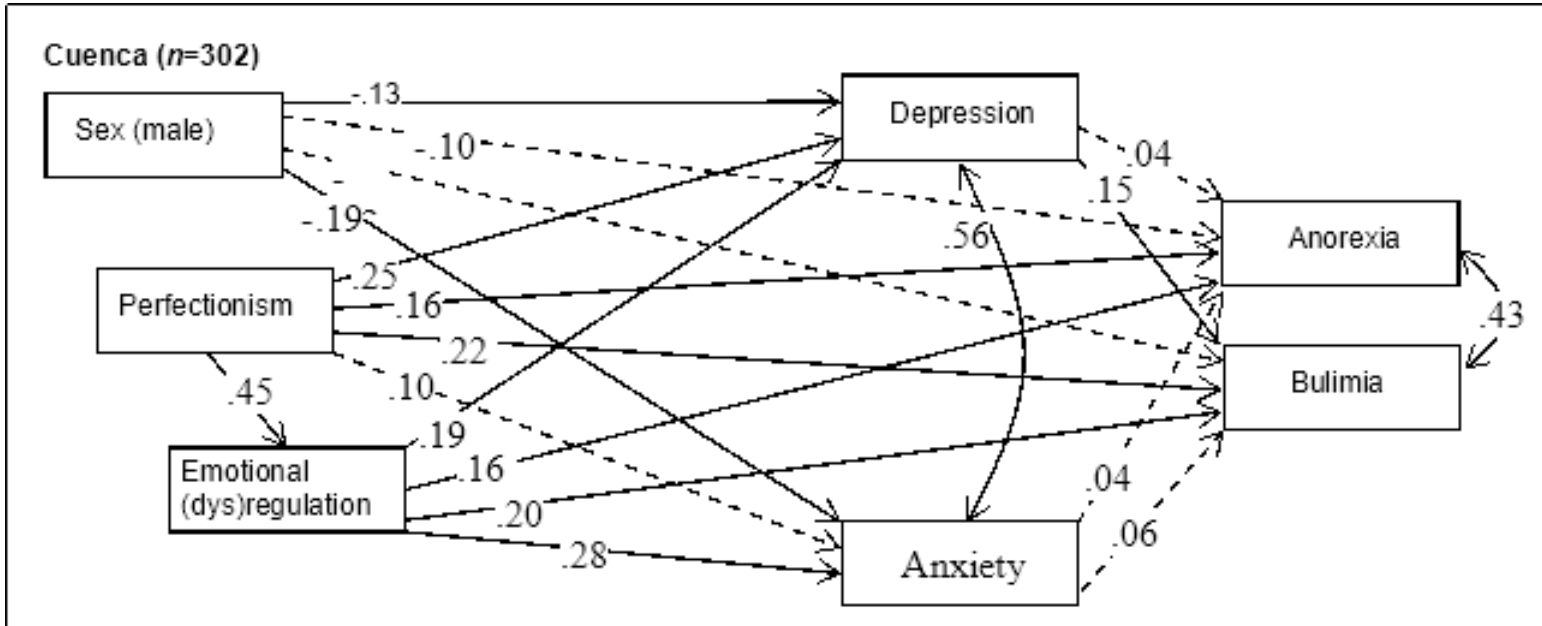

\section{Quito ( $n=306)$}

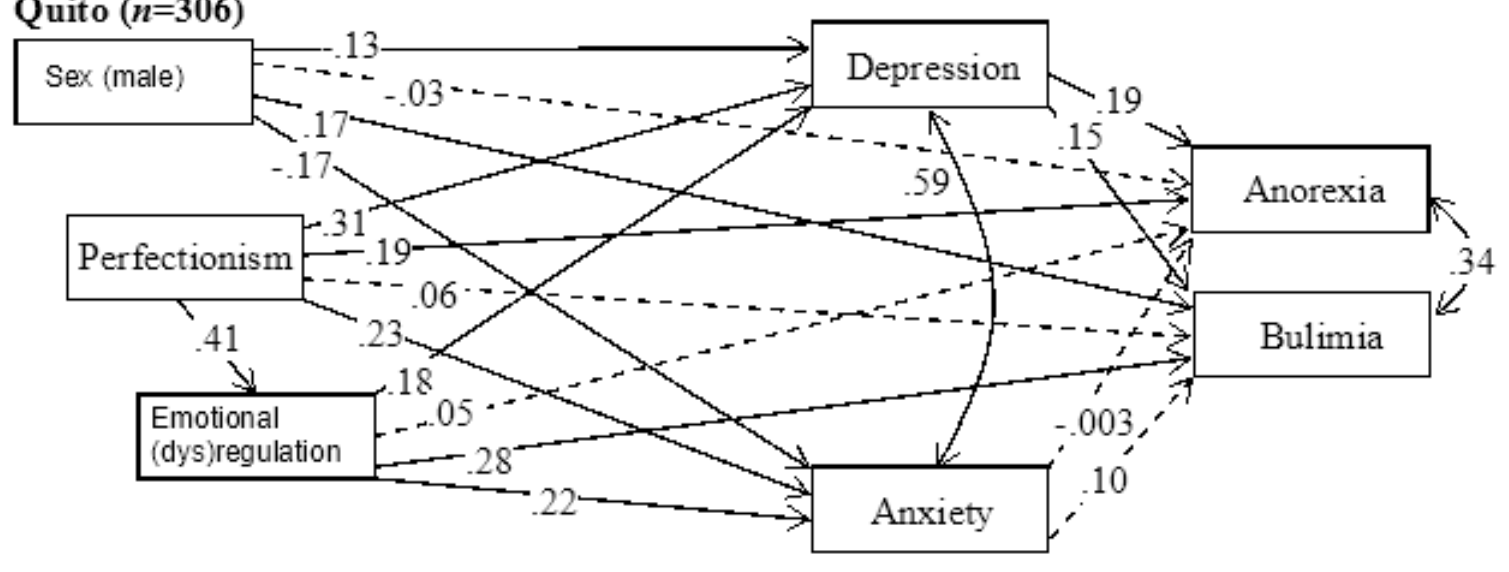

\section{Guadayaquil}

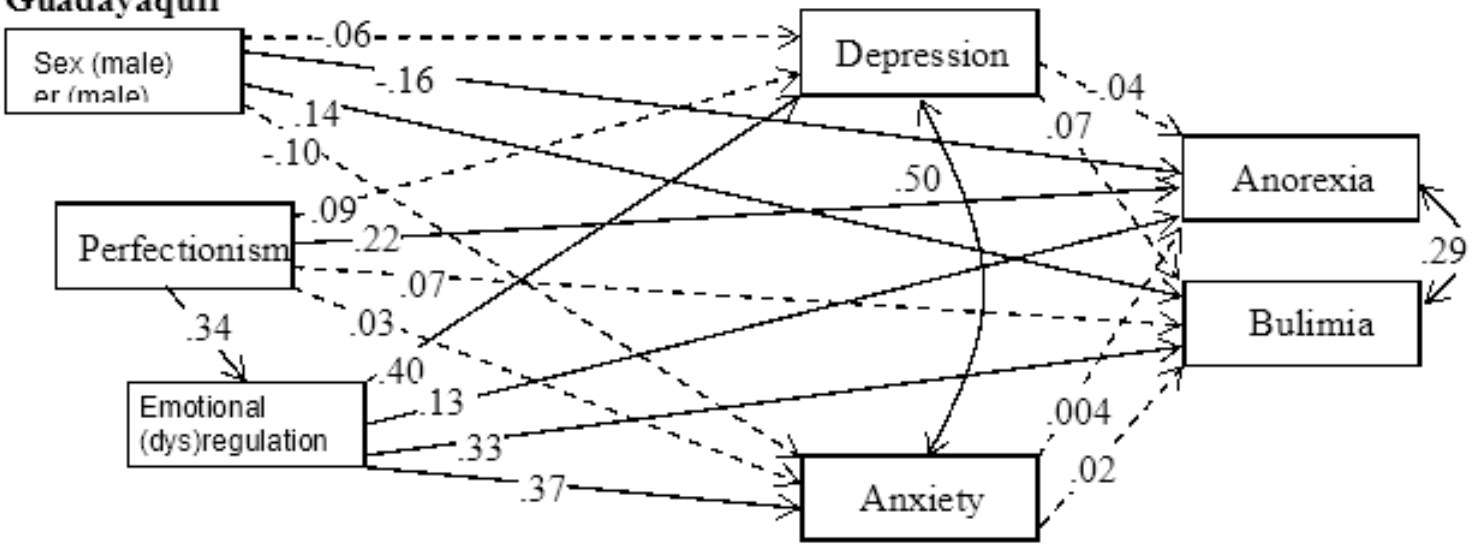

\section{Figure 1}

Path-diagram obtained in the SEM: standardized coefficients Note. Continuous lines: significant coefficients $(p \leq .05)$. Dash lines: non-significant coefficients.

\section{Supplementary Files}


This is a list of supplementary files associated with this preprint. Click to download.

- Tables1.docx 